D.O.I: $10.3895 / \mathrm{S} 1808-04482013000200006$

\title{
PONDERAÇÃO DO IMPACTO AMBIENTAL DOS RESÍDUOS E SUBPRODUTOS DA PRODUÇÃO INDUSTRIAL SUCROENERGÉTICA
}

\section{WEIGHTING OF ENVIRONMENTAL IMPACT OF WASTES AND BY- PRODUCTS OF SUGAR ENERGY INDUSTRIAL PRODUCTION}

\author{
Marcelo Giroto Rebelato ${ }^{1}$; Leonardo Lucas Madalenoㄹ; Andréia Marize Rodrigues ${ }^{3}$; \\ ${ }^{1}$ Universidade Estadual Paulista Júlio de Mesquita Filho - UNESP - Jaboticabal - SP - Brasil \\ mgiroto@fcav.unesp.br \\ ${ }^{2}$ Centro Estadual de Educação Tecnológica Paula Souza - FATEC - Jaboticabal - SP - Brasil \\ leoagro@gmail.com \\ ${ }^{3}$ Universidade Estadual Paulista Júlio de Mesquita Filho - UNESP - Jaboticabal - SP - Brasil \\ andreiamarize@fcav.unesp.br
}

\begin{abstract}
Resumo
O objetivo deste trabalho é desenvolver e apresentar um inventário dos resíduos e subprodutos da produção sucroenergética e, a partir disso, realizar a ponderação quantitativa do impacto ambiental relativo de cada um deles. Para isso foram mapeadas e analisadas as etapas produtivas da produção sucroenergética e identificados os resíduos e subprodutos gerados em cada uma delas. Em seguida, aplicou-se o método Analytic Hierarchy Process (AHP) para o estabelecimento dos pesos relativos de cada resíduo ou subproduto em termos do seu impacto potencial no meio ambiente. Como resultado, identificamos vinte e um resíduos e subprodutos da produção sucroenergética potencialmente poluidores. Esses resíduos/subprodutos foram caracterizados em função da sua composição físico/química e forma pela qual são gerados no âmbito dos processos de fabricação. Concluímos também que a produção do açúcar e do etanol apresenta maior impacto ambiental relativo nas águas (67\%), seguido por solo (23\%) e atmosfera (10\%).
\end{abstract}

Palavras-chave: impacto ambiental da produção sucroenergética; resíduos e subprodutos da produção sucroenergética; ponderação do impacto ambiental dos resíduos da produção sucroenergética.

\section{Introdução}

A agroindústria sucroenergética, apesar de toda tradição e da importância na economia nacional, tem sido alvo de inquietações e julgamentos críticos relativamente aos impactos ambientais negativos que seus processos industriais produzem no meio ambiente (PIACENTE, 2005; MACHADO; SILVA, 2010). O processamento industrial da cana de açúcar apresenta uma cadeia produtiva em que várias de suas etapas, se não gerenciadas adequadamente, podem provocar impactos ambientais indesejados principalmente associados ao solo e à água (ANA, 2009). 
Além da utilização intensiva da água como insumo produtivo, a produção do etanol e do açúcar é geradora de resíduos como a vinhaça, o bagaço, a torta de filtro, a flegmaça, efluentes da lavagem de pisos e equipamentos, etc. os quais podem causar impactos significativos ao meio ambiente. Em bacias hidrográficas com menor disponibilidade de água, pode ser também um competidor expressivo pelos recursos hídricos, com destaque nas regiões em que a cana de açúcar necessite de irrigação plena. Desta forma, o processo de tomada de decisão dentro do contexto da gestão ambiental eficaz envolve não somente a conformidade legal da atividade industrial mas também a demonstração de responsabilidade social por parte das usinas (ANA, 2009).

Observa-se que mesmo já sendo regido por um grande conjunto de leis com vistas à regulação de suas atividades visando à prevenção e à minimização dos impactos ambientais de suas operações (OLIVEIRA et al, 2009), o setor vem constantemente apresentando posturas mais modernas na gestão das suas atividades industriais a partir da adoção de ações e contramedidas que visam mitigar os efeitos prejudiciais dos resíduos e subprodutos ao meio ambiente (MACHADO; SILVA, 2010).

A busca por objetivos produtivos alinhados às questões ambientais está, no entanto, ligada à necessidade do desenvolvimento de indicadores de desempenho ambiental que possam não somente apontar os impactos ambientais atuais das operações industriais, mas que também possam indicar a evolução da atuação ambiental da empresa a partir de intervenções com vistas à melhoria deste desempenho (ROHRICH; CUNHA, 2004). Neste contexto, apesar de a pesquisa dentro da literatura especializada revelar um grande número de trabalhos existentes sobre os resíduos poluentes da indústria sucroenergética e de seus impactos ambientais, observa-se que os trabalhos dedicados ao desenvolvimento de indicadores ambientais especificamente aplicados aos efeitos das atividades de processamento industrial da cana de açúcar são escassos. Ademais, não se encontra disponível nenhuma produção acadêmica ou profissional que apresente uma listagem exaustiva e completa de todos os resíduos e subprodutos industriais nesta atividade. Além disso, não existem trabalhos que avaliem o impacto ambiental relativo de cada resíduo/subproduto gerado pelas operações produtivas do açúcar e do etanol.

A partir da problemática acima exposta, este trabalho possui dois objetivos principais: desenvolver e apresentar um inventário dos resíduos e subprodutos da produção sucroenergética e, a partir disso, realizar a ponderação quantitativa do impacto ambiental relativo de cada um deles. É importante frisar que não constitui objetivo deste artigo abarcar os resíduos e subprodutos das etapas realizadas na área agrícola, quais seja plantação, cultivo, corte e carregamento da cana de açúcar. O trabalho é relevante na medida em que contribui com a reflexão da sustentabilidade no setor sucroenergético, com o desenvolvimento de indicadores mais eficazes aplicados à avaliação dos impactos ambientais provocados pelas empresas do setor e como subsídio para 
desenvolvimento de metodologias de gestão ambiental que contribuam na minoração do passivo ambiental de suas atividades industriais.

\section{Metodologia de desenvolvimento}

Para chegar-se ao primeiro objetivo traçado, desenvolver e apresentar um inventário dos resíduos e subprodutos potencialmente poluidores da produção do açúcar e do etanol, a metodologia utilizada foi composta de duas etapas:

1. Mapeamento das etapas produtivas da produção sucroenergética - nesta etapa realizamos a identificação e o estudo das operações necessárias para a transformação do caldo extraído da cana em açúcar e etanol;

2. Identificação e estudo dos resíduos e subprodutos gerados em cada etapa produtiva nesta etapa percorremos dois caminhos distintos:

a) Uma pesquisa dentro da bibliografia especializada visando identificar quais os resíduos e subprodutos gerados e suas características;

b) Uma pesquisa em campo em cinco usinas sucroenergéticas da Bacia Hidrográfica do Rio Mogi Guaçu. A escolha das usinas foi realizada por conveniência e em cada uma foram entrevistados os responsáveis pelas áreas de produção e gestão ambiental. O objetivo desta etapa foi complementar a etapa anterior de modo a obtermos um inventário fidedigno e exaustivo dos resíduos e subprodutos gerados pelas usinas.

Para o segundo objetivo traçado, realizar a ponderação quantitativa do impacto ambiental relativo de cada resíduo/subproduto identificado no objetivo anterior, utilizamos a o Método de Análise Hierárquica de Processos ou Analytic Hierarchy Process (AHP). O AHP foi desenvolvido na Wharton School of Business para servir como ferramenta de apoio a decisões sobre problemas complexos e é apresentado em Saaty (1991). A metodologia consiste em montar-se uma estrutura hierárquica mostrando os relacionamentos existentes, partindo-se de um objetivo geral até chegar-se às diversas alternativas, conforme a Figura 1 (CASTRO et al, 2005).

O AHP é baseado em três princípios do pensamento analítico (COSTA et al, 2011):

a) Construção de hierarquias: o problema deve ser estruturado em níveis hierárquicos, como forma de buscar uma melhor compreensão e avaliação, sendo parte fundamental do processo de raciocínio humano. No exercício desta atividade, identificam-se os elementos chave para a tomada de decisão, agrupando-os em conjuntos afins, os quais são alocados em camadas especificas;

b) Definição de prioridades: o ajuste das prioridades no AHP fundamenta-se na habilidade do ser humano de perceber o relacionamento entre objetos e situações observadas, comparando pares à luz de um determinado foco ou critério (julgamentos paritários); 
c) Consistência lógica: no AHP, é possível avaliar o modelo de priorização construído quanto à sua consistência.

Figura 1 - Estrutura de decisão hierárquica no método AHP

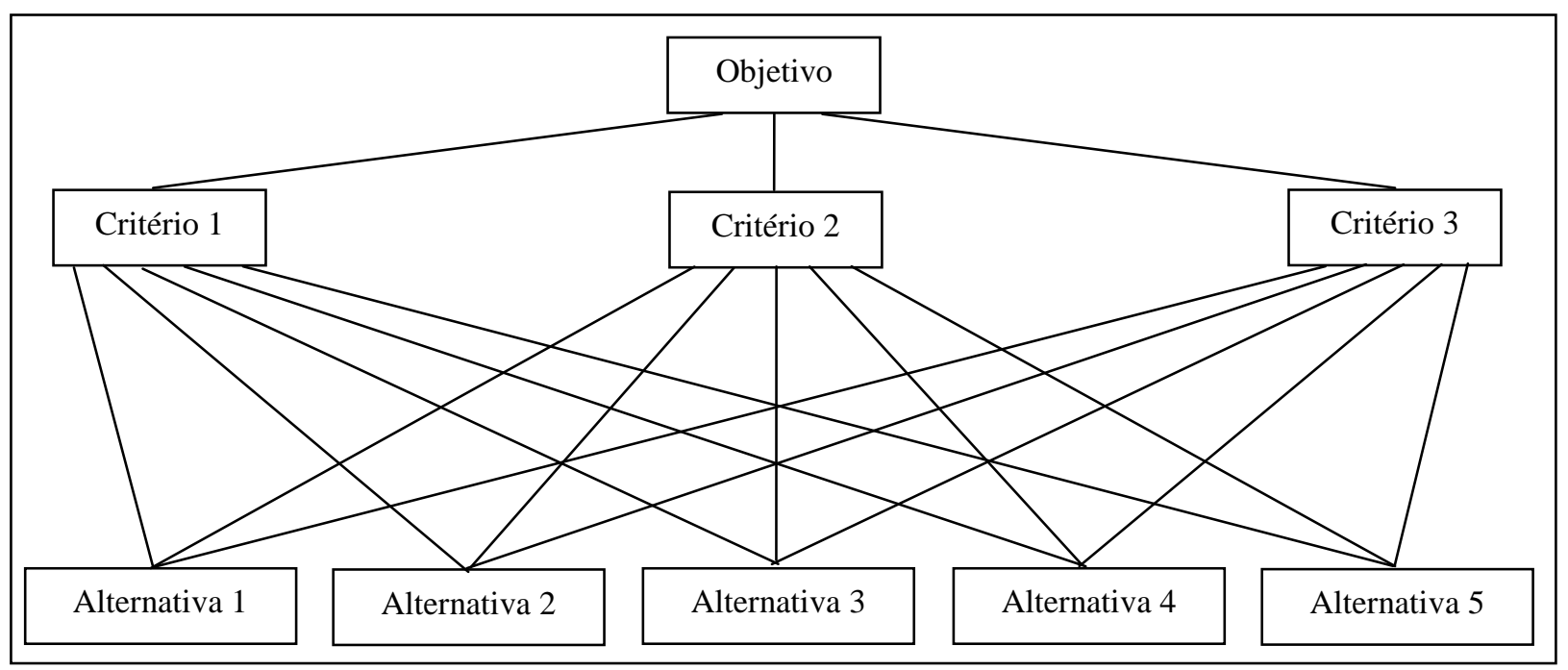

Fonte: Autoria própria

A estruturação de um problema AHP começa com a definição do objetivo global desejado. A partir desse objetivo definem-se os critérios numa estrutura em árvore, sendo o objetivo principal a raiz desta árvore. À medida que nos afatamos da raiz, temos fatores mais específicos, e os extremos (as "folhas") representam os fatores ou critérios de avaliação. Para cada grupo de critérios semelhantes que possuem um mesmo "pai”, uma matriz de comparações paritárias (MCP), contendo os níveis de preferência obtidos por comparação de um fator com outro deve ser preenchida. O princípio do AHP é a geração de um vetor de prioriades pelo cálculo do maior autovetor de cada MCP do problema inteiro (SHIMIZU, 2010). As comparações paritárias são obtidas por questionamento direto às pessoas (um único indivíduo, se o problema é do seu interesse apenas) que podem ou não ser especialistas, mas que estejam familiarizadas com o problema. Um ponto central é que as pessoas muitas vezes são inconsistentes. No entanto, as prioridades têm que ser definidas e as coisas têm de ser feitas a despeito da inconsistência (SAATY, 1991).

No método AHP, as comparações paritárias não são feitas em escala absoluta devido à natureza dos componentes de uma decisão múlti critérios. Dado que muitas vezes o problema é abstrato, isso dificulta que isoladamente os componentes sejam mensurados, principalmente usando a mesma escala. Na comparação dois a dois, quando o tomador de decisão exprimir sua preferência por um atributo "X", como sendo muito mais importante do que o atributo "Y" por exemplo, estará atribuindo para o atributo " $\mathrm{X}$ " peso " 5 " Caso o tomador de decisão considere que os dois critérios possuem a mesma importância, estará atribuindo o peso " 1 ”. A Tabela 1 define e explica o conceito dos pesos utilizados no método AHP (OLIVEIRA et al, 2011). 
Tabela 1 - Fatores para as comparações paritárias

\begin{tabular}{|c|c|l|}
\hline $\begin{array}{c}\text { Intensidade de } \\
\text { importância (peso) }\end{array}$ & \multicolumn{1}{|c|}{ Peso } & \multicolumn{1}{c|}{ Explicação } \\
\hline $\mathbf{1}$ & \multicolumn{1}{|c|}{ Mesma importância } & $\begin{array}{l}\text { Os dois atributos contribuem igualmente } \\
\text { para o objetivo }\end{array}$ \\
\hline $\mathbf{3}$ & $\begin{array}{l}\text { Importância pequena de um sobre o } \\
\text { outro }\end{array}$ & $\begin{array}{l}\text { A experiência e o julgamento favorecem } \\
\text { levemente um atributo em relação ao } \\
\text { outro }\end{array}$ \\
\hline $\mathbf{5}$ & Importância grande ou essencial & $\begin{array}{l}\text { A experiência e o julgamento favorecem } \\
\text { fortemente um atributo em relação ao } \\
\text { outro }\end{array}$ \\
\hline $\mathbf{7}$ & Importância muito grande & $\begin{array}{l}\text { Um atributo é fortemente favorecido em } \\
\text { relação ao outro; sua dominação de } \\
\text { importância é demonstrada na prática }\end{array}$ \\
\hline $\mathbf{9}$ & \multicolumn{1}{|c|}{ Importância absoluta } & $\begin{array}{l}\text { A evidência favorece um atributo em } \\
\text { relação ao outro com o mais alto grau de } \\
\text { certeza }\end{array}$ \\
\hline $\mathbf{2 , 4 , 6 , 8}$ & $\begin{array}{l}\text { Valores intermediários entre os } \\
\text { valores adjacentes }\end{array}$ & $\begin{array}{l}\text { Quando se procura uma condição de } \\
\text { compromisso entre duas definições }\end{array}$ \\
\hline
\end{tabular}

Fonte: OLIVEIRA et al $(2011, \mathrm{p} .6)$

Para a realização prática dos julgamentos paritários pelo método AHP escolhemos o software Make It Rational (http://makeitrational.com/features). Existem no mercado muitos softwares de apoio à decisão os quais utilizam o método AHP. Este software foi escolhido por conter uma interface gráfica bastante amigável, por organizar o processo de avaliação multi critérios de maneira bastante lógica e de fácil compreensão e por permitir que a avaliação seja realizada por diferentes avaliadores, calculando automaticamente a razão de consistência (CR) da hierarquia.

Para as comparações paritárias do método AHP realizadas neste estudo foi escolhida uma equipe de quatro especialistas em gestão ambiental e conhecedores das características da produção sucroenergética, todos eles já tendo trabalhado no setor por um período de pelo menos quatro anos. A Tabela 2 traz as características da composição da equipe de avaliadores. O processo de entrada dos dados no software Make It Rational foi realizado por meio do consenso entre os especialistas. Ou seja, para cada avaliação paritária, tanto para os critérios de decisão quanto para as alternativas de decisão, buscou-se consenso entre os membros da equipe.

Tabela 2 - Características da equipe de especialistas avaliadores

\begin{tabular}{|c|c|c|c|}
\hline Avaliador & $\begin{array}{c}\text { Experiência na produção } \\
\text { sucroalcooleira }\end{array}$ & $\begin{array}{c}\text { Experiência em gestão } \\
\text { ambiental }\end{array}$ & Formação \\
\hline A & 5 anos & 7 anos & Engenheiro Agrônomo \\
\hline B & 6 anos & 10 anos & Físico \\
\hline C & 4 anos & 6 anos & Engenheiro ambiental \\
\hline D & 4 anos & 4 anos & Engenheiro de Produção \\
\hline
\end{tabular}

Fonte: Autoria própria

\section{A produção sucroenergética e seus resíduos e subprodutos}

A Figura 2 apresenta simplificadamente os processos sucroenergéticos. Na figura apresentam-se na cor preta os processos produtivos, em azul os resíduos gerados e em vermelho os subprodutos. Conceituamos como resíduo é tudo o que é produzido e que não pode ser aproveitado economicamente. Já para poder ser considerado como subproduto, segundo Fipa (2007), a 
substância ou material deve atender aos seguintes requisitos: (1) existir uma utilização futura para este; (2) poder ser utilizado diretamente, ou seja, sem sofrer alterações; (3) fazer parte integrante de um processo de produção contínuo. Concluímos desta forma, que tanto os resíduos como os subprodutos podem ser poluentes, pois poluente é o material ou substância introduzida num sistema natural não adaptada a ele, ou que não suporta as quantidades que nele são introduzidas.

Observa-se, pela Figura 2, que a industrialização da cana de açúcar começa com o descarregamento na usina (recepção da cana). Depois de descarregada a cana é limpa por meio de processo de lavagem com água ou por meio de limpeza a seco. O processo de lavagem com água gera como resíduo o efluente da lavagem da cana. O processo de lavagem a seco separa a palha, a qual é conduzida para a caldeira na cogeração de energia.

Em seguida, vem a etapa de extração do caldo, geralmente realizada por meio de moendas ou difusores. Na extração separa-se o caldo da cana (produto) do bagaço (subproduto). O bagaço será utilizado também (em maior proporção do que a palha) para alimentar as caldeiras onde será queimado para a cogeração de energia. Neste processo geram-se como subprodutos as cinzas da queima do bagaço e os materiais particulados que saem pela chaminé da caldeira. Como resíduos são gerados os gases da queima do bagaço, o efluente do tratamento dos gases de combustão, o efluente e o lodo proveniente da descarga das caldeiras.

O caldo extraído segue ao processo de sulfitação (considerando-se que o processo está direcionado à produção do açúcar cristal branco, ou direto para a caleagem para a produção de açúcar bruto - VHP) o qual promove a redução do seu pH de valores entre 5 a 5,50 para 3,8 a 4,3. Em seguida, o caldo segue ao processo de caleagem (mistura com leite de cal - $\mathrm{CaOH}_{2}$ ) para elevação do pH e então é aquecido. O aquecimento tem a finalidade de acelerar a coagulação e floculação de colóides e não-açúcares protéicos, emulsificar graxas e ceras e possibilitar a degasagem do caldo. Depois de aquecido e adicionado polímero, o caldo clarificado é separado do lodo (colóides formados) por meio da sedimentação em decantadores de bandejas ou sem bandejas. O lodo do fundo do decantador é enviado para filtração visando a recuperação do açúcar ali contido. Após sair do decantador, o lodo recebe pequena quantidade de polímero, o qual auxilia na separação das impurezas, e recebe também adição de bagacilho com o objetivo de aumentar o rendimento dessa extração. O caldo filtrado retorna para o processo de clarificação e o material retido nos filtros recebe o nome de torta de filtro. Esse subproduto pode ser enviado à compostagem e, a seguir, à lavoura para ser utilizado como adubo (REBELATO et al, 2011).

Depois da decantação segue-se a etapa de concentração do caldo (realizada em evaporadores de múltiplo efeito), que consiste na retirada de água do caldo para o aumento da concentração de sólidos solúveis ( ${ }^{\circ}$ Brix) para uma faixa entre $60^{\circ}$ a $65^{\circ}$ Brix, quando passa a receber o nome de xarope. O processo de concentração do caldo gera como resíduos o efluente dos condensadores 
barométricos ou dos multijatos e o efluente condensado nos evaporadores.

O xarope segue para o processo de cozimento, cujo objetivo é cristalizar o máximo da sacarose presente no xarope. Esse esgotamento (transformação de parte da sacarose contida no xarope em cristais) não pode ser feito somente em um cozimento e, geralmente, as usinas possuem conjuntos de cozedores A, B e C. No fluxograma da Figura 2 se observam somente os conjuntos A e $\mathrm{B}$, que é o esquema mais usado em usinas que produzem etanol e açúcar. Cada conjunto de cozedores possui um sistema de cristalização separado e seguido de centrífugas. Para o eixo dos cozedores A observa-se as centrífugas "de batelada" (as quais não quebram os cristais de açúcar) e no eixo dos cozedores da massa B temos a centrífuga contínua (de separação mais eficiente, entretanto, ela quebra os cristais, os quais depois são transformados em magma, que é o açúcar “quebrado" misturado com caldo clarificado ou xarope).

Os aparelhos cristalizadores localizados abaixo dos cozedores têm a função de armazenar a massa cozida (cristais de açúcar + mel) produzida nos cozedores até a centrifugação. As centrífugas, por sua vez, são responsáveis por separar os cristais do mel. O último mel é o resíduo gerado na produção de açúcar. No processo com duas massas (A e B), é gerado mel o A e o mel B (ou melaço, que é um subproduto), respectivamente.

Observa-se que há adição de mel A no cozedor B e esse é concentrado até atingir a supersaturação. Em seguida, é adicionada a "semente" (cristais de açúcar quebrados misturados com etanol, produzido pelo laboratório industrial da usina), que é o método que proporciona maior padronização do tamanho de açúcar final desejado. Para a semente de açúcar crescer, é necessário que seja adicionado maior quantidade de mel A (para aumentar a quantidade de sacarose no meio). Essa alimentação com mel A é realizada até que o tamanho dos cristais seja adequado e tem a função de fornecer água (para não sair da zona metaestável de saturação) e sacarose (para o crescimento do cristal de açúcar). Em seguida, o processo é interrompido e a massa cozida B produzida é enviada aos cristalizadores. Do aparelho de cristalização, a massa cozida B é encaminhada para a centrífuga contínua que fará a separação dos cristais do mel. Os cristais são quebrados pela força da ação centrífuga e são encaminhados para a formação de magma, enquanto o melaço é direcionado para a produção de etanol (preparo do mosto) (REBELATO et al, 2011). 
Figura 2 - Fluxograma simplificado da produção industrial sucroenegética com destaque para os resíduos e subprodutos

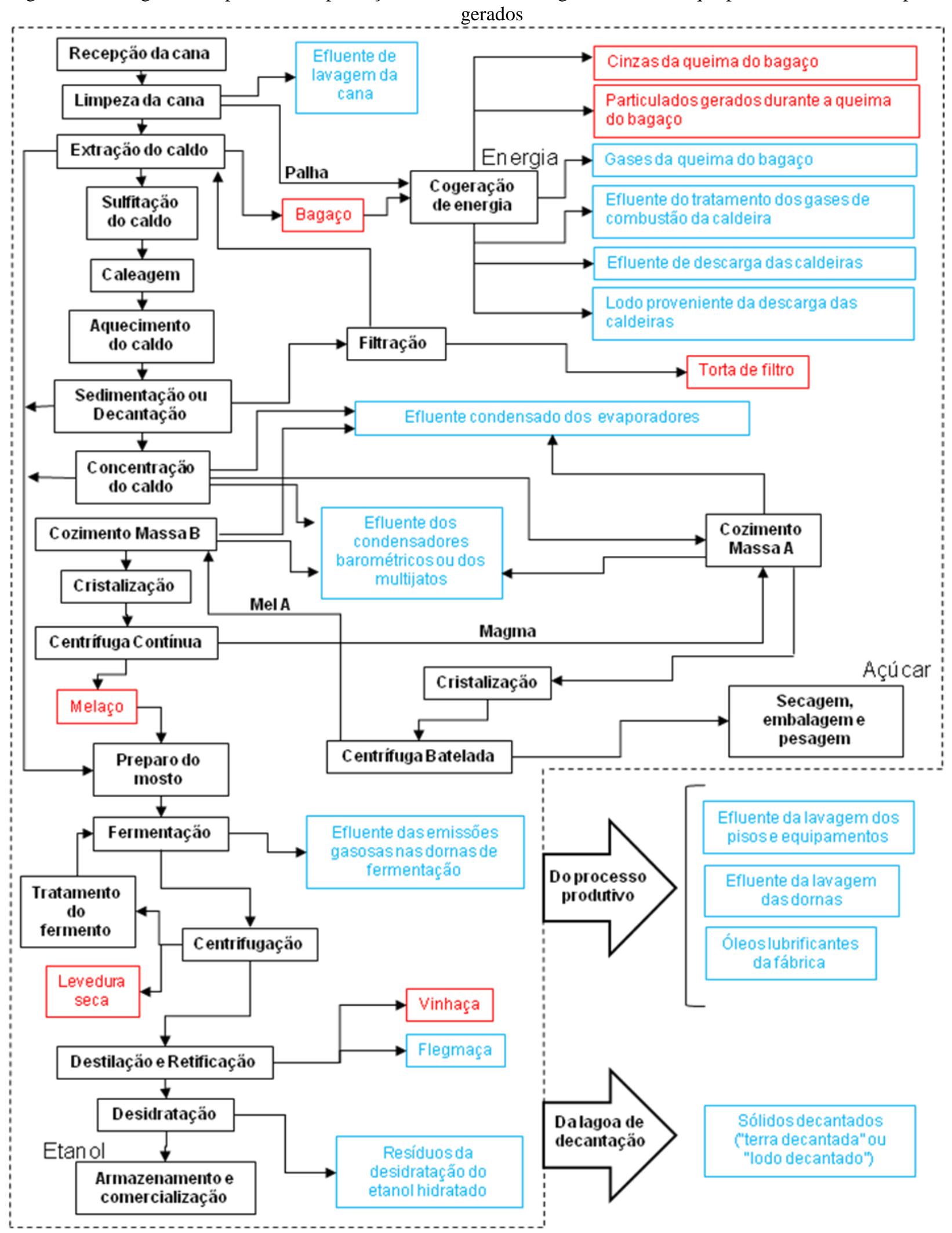

Fonte: elaboração própria

O magma vai para o cozedor A e se encontra em supersaturação. Não é necessária a adição de sementes, pois o magma contém os pequenos cristais que crescerão com a alimentação realizada com xarope que vem do processo de concentração do caldo. Após atingir o tamanho desejado dos 
cristais no cozedor A, a massa cozida é encaminhada para o cristalizador, e em seguida, para a centrifugação na centrífuga "de batelada”. O açúcar comercial é separado e enviado para as etapas finais de produção (secagem, embalagem e pesagem). O mel A, por sua vez, é encaminhado para o armazenamento e será usado no cozedor B para continuar o processo de esgotamento. Observa-se que os processos de cozimento (A e B) também são geradores de efluentes dos condensadores barométricos ou dos multijatos e de efluente condensado nos evaporadores (REBELATO et al, 2011).

Na produção do etanol pode-se utilizar como matéria prima o caldo extraído da cana, o caldo clarificado, o xarope e o melaço (subproduto da produção do açúcar), o qual ainda é rico e concentrado em sacarose, glicose e frutose. A produção do etanol se inicia com o preparo do mosto. Este preparo começa com a correção da concentração da matéria-prima utilizada com a redução do $\mathrm{pH}$ para 4,5, com o acerto da temperatura para em torno de $32^{\circ} \mathrm{C}$, e com o suprimento de deficiências nutricionais. Após a etapa de preparo do mosto realiza-se a mistura deste com fermento selecionado da espécie Saccharomyces cerevisiae e inicia-se a etapa de fermentação. Por meio desse processo obtém-se o vinho levedurado. Em seguida, este vinho passará pela centrifugação com objetivo de separar o vinho da levedura. Uma parte do fermento é encaminhado para o setor de tratamento para diminuir a contaminação com bactérias e utilizar novamente o levedo num novo ciclo de fermentação. Outra parte do fermento, resultante da multiplicação das leveduras durante o processo fermentativo, é direcionada para o processo de secagem para produção de levedura seca, subproduto que é apreciado para ser utilizado na alimentação animal, por conter muita proteína (REBELATO et al, 2012).

Durante o processo de fermentação também há produção do gás $\mathrm{CO}_{2}$, que pode ser considerado um efluente das emissões gasosas nas dornas de fermentação. O gás arrasta etanol e deve passar pela torre de $\mathrm{CO}_{2}$ para recuperar o álcool arrastado. $\mathrm{O}$ vinho delevurado (sem levedura) é então encaminhado para o processo de destilação.

A destilação consiste na separação das substâncias que compõem o vinho, basicamente água, etanol, alcoóis superiores, ácidos orgânicos, aldeídos, ésteres e outros através de seus diferentes pontos de ebulição. Em primeiro lugar, o vinho é levado para a destilação na coluna "A/A1/D" (levando-se em consideração que em alguns processos não é utilizada a coluna $\mathrm{D}$ ), na qual se injeta vapor e vinho quente e se têm três saídas: (1) a vinhaça (subproduto, em geral, utilizado na fertirrigação), (2) o etanol de cabeça ou "de segunda", uma mistura hidroalcoólica com teor de $92^{\circ}$ a $94^{\circ} \mathrm{GL}$, que sai no topo da coluna (D) (quando não existe a coluna $\mathrm{D}$, o condensado é enviado à coluna B); e o (3) flegma, uma mistura de vapores hidroalcoólicos de $45^{\circ}$ a $50^{\circ} \mathrm{GL}$, que sai da lateral (entre as colunas A1 e A) que é submetido a um segundo processo de destilação, o de retificação (MARAFANTE, 1993). 
Na segunda destilação, realizada na coluna "B/B1", se eleva o grau alcoólico e se eliminam parte das impurezas existentes. Nesta etapa tem-se a produção de etanol hidratado $\left(92,6^{\circ}\right.$ INPM ou 97\% v/v - esta é atualmente é a forma mais usual nas usinas), de flegmaça (resíduo da retificação do flegma), de óleo fúsel (que é um subproduto, uma mistura concentrada das impurezas de cauda alcoóis superiores como o isoamílico) e de etanol "de segunda", rico em frações "de cabeça" (aldeídos e ésteres). O etanol de segunda ou bruto, apesar de ser um subproduto, é normalmente utilizado pelas usinas, ou como combustível na caldeira ou introduzido novamente no processo (na dorna volante) para passar novamente pelas colunas destiladoras. O óleo fúsel é um subproduto de alto valor de mercado e por isso é sempre comercializável. A flegmaça é um efluente normalmente incorporado à vinhaça ou às águas residuárias. $\mathrm{O}$ processo prossegue rumo à produção do etanol anidro (99,3 INPM ou 99,6\% v/v) através de sua desidratação na coluna "C" (MARAFANTE, 1993).

Existem três métodos para desidratar o etanol hidratado: o extrativo, o azeotrópico e a peneira molecular. No primeiro caso são adicionadas substâncias que aprisionam a água e assim possibilitam separar a água do etanol na destilação. A substância mais utilizada nesse método é o monoetilenoglicol (MEG). No método azeotrópico é utilizado o ciclohexano, o qual gera uma substância ternária de menor ponto de ebulição, retendo então a molécula de água. Esses dois métodos de desidratação são utilizados na coluna $\mathrm{C}$ e os produtos utilizados recuperados na coluna $\mathrm{P}$ (com o ciclohexano também existe o decantador que auxilia na recuperação do produto). Quando se utiliza o MEG, o etanol anidro é retirado no topo da coluna $\mathrm{C}$, enquanto que quando se utiliza o ciclohexano, o etanol de graduação $99,6 \%$ v/v sai na base da coluna C. Nos dois métodos as substâncias adicionadas são recuperadas e reutilizadas. A peneira molecular, no entanto, é método mais caro de desidratação e possui elevada capacidade de adsorção seletiva porque é constituída de um mineral especial para este fim denominado zeólita. Esse equipamento é construído de forma a reter a água à medida em que o etanol passa. Retira-se, por meio deste método, etanol anidro de alta qualidade, sem resíduos químicos. Por isso, é o método preferido para o etanol que é exportado (REBELATO et al, 2012).

Após o processo de destilação o etanol é enviado para tanques especiais de armazenamento. Depois de comercializados, o etanol hidratado ou anidro é transportado até as empresas distribuidoras e por fim, chegam ao consumidor final.

A partir dos processos produtivos identificamos também a geração de três resíduos: (1) o efluente da lavagem dos pisos e equipamentos, gerados na lavagem geral de equipamentos e pisos; (2) o efluente da lavagem das dornas, produzido na assepsia das dornas que trabalham no processo descontínuo de fermentação; (3) os óleos lubrificantes da fábrica, que são os óleos trocados periodicamente de máquinas como turbinas, sistemas hidráulicos, engrenagens, etc. 
Finalmente, das lagoas de decantação temos a geração sólidos decantados ("terra decantada", "lodo decantado" ou "lodo primário bruto"). Estes sólidos decantados nas lagoas são coletados, geralmente no final da safra, e enviados à lavoura como adubo.

\section{Resultados e discussões}

Com vistas à priorização pretendida e à decomposição da complexidade do sistema ponderativo foi criada uma estrutura hierárquica de interesse direcionada pelas três entidades ambientais básicas: solo, águas e atmosfera. Estas três entidades figuraram como os critérios de avaliação, os quais foram utilizados como balizadores na avaliação paritária das alternativas. Essas alternativas são os vinte e um resíduos e subprodutos identificados na Figura 2, os quais podem ser vistos na estrutura hierárquica por meio da Figura 3.

$\mathrm{Na}$ avaliação AHP considerou-se o impacto potencial dos resíduos/subprodutos tomando como hipótese o despejo sendo lançado diretamente no meio ambiente. Por exemplo, na comparação paritária entre a vinhaça e a flegmaça, sob o ponto de vista do critério do "impacto nas águas", tomaram-se como hipótese ambos os efluentes sendo despejados diretamente em cursos de água. Neste caso, os avaliadores ponderaram uma relação de 7:1, ou seja, a alternativa "vinhaça" foi considerada (tendo como referência a Tabela 1) fortemente dominante com relação à alternativa "flegmaça". Isso porque a vinhaça é um resíduo altamente poluidor, o qual apresenta altíssimos níveis de DBO (demanda bioquímica de oxigênio), enquanto a flegmaça é constituída basicamente por água com traços de óleo fúsel e baixos níveis de DBO. 
Figura 3 - Estrutura hierárquica para a ponderação dos resíduos e subprodutos

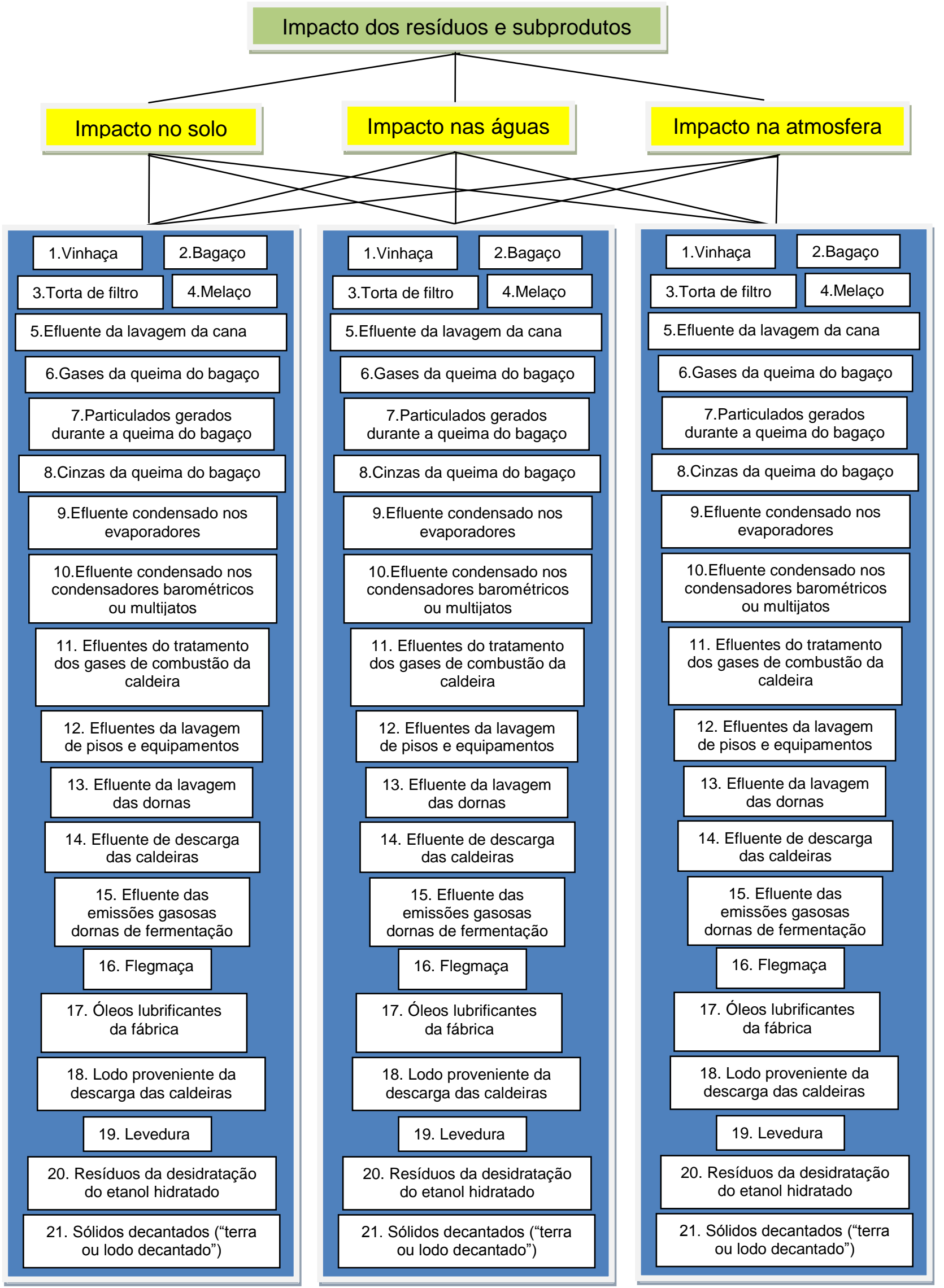

Fonte: elaboração própria 
A Figura 4 apresenta os resultados das comparações paritárias feitas por meio do software já citado considerando-se os três critérios: impacto na atmosfera, impacto nas águas, impacto no solo. Pode-se observar que, a partir das ponderações feitas pela equipe de especialistas participantes do estudo, a produção industrial sucroenergética apresenta maior impacto ambiental relativo nas águas (67\%), seguido por solo (23\%) e atmosfera (10\%). A Figura 5 mostra uma visualização gráfica dos resultados obtidos por meio da aplicação do método nas comparações paritárias entre todos os resíduos/subprodutos. A Tabela 3 apresenta os resultados quantificados (totais e parciais para atmosfera, águas e solo) correspondentes à Figura 5.

Por meio da Figura 5 foi possível identificar visualmente três grupos distintos de poluentes. O grupo mais poluente vai da vinhaça ao bagaço. Identificamos este de grupo como de alto impacto ambiental. O segundo grupo, de médio impacto ambiental, vai do efluente de lavagem das dornas até as cinzas da queima do bagaço. E o terceiro grupo, de baixo impacto ambiental, vai dos sólidos decantados nas lagoas de sedimentação até os efluentes de descarga de caldeira. Estes três grupos estão identificados pelas cores azul, amarelo e verde na Tabela 3.

Figura 4 - Resultados das comparações paritárias entre os critérios da hierarquia criada

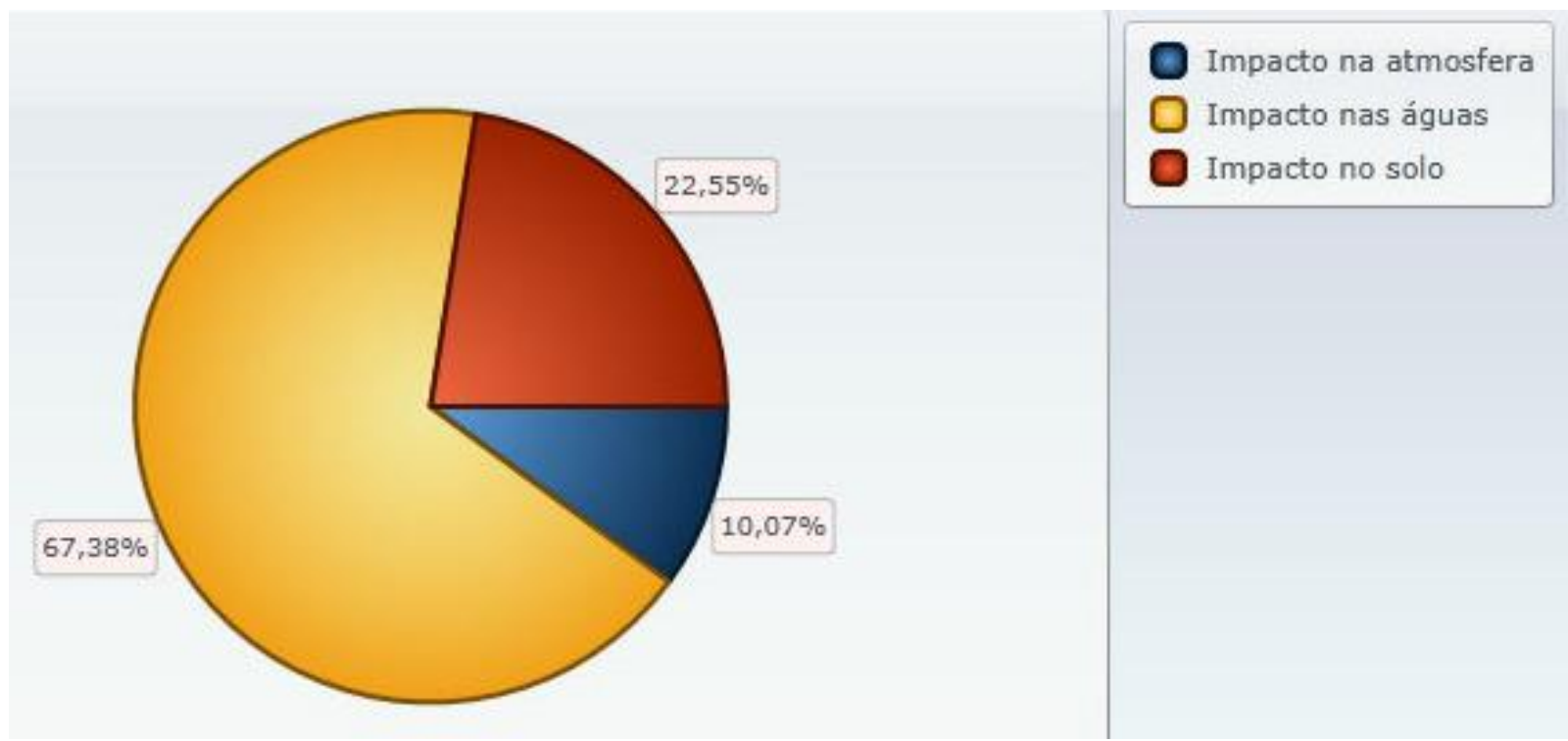

Fonte: elaboração própria 
Figura 5 - Resultados gráficos da aplicação do método AHP nas comparações paritárias entre todos os resíduos e subprodutos

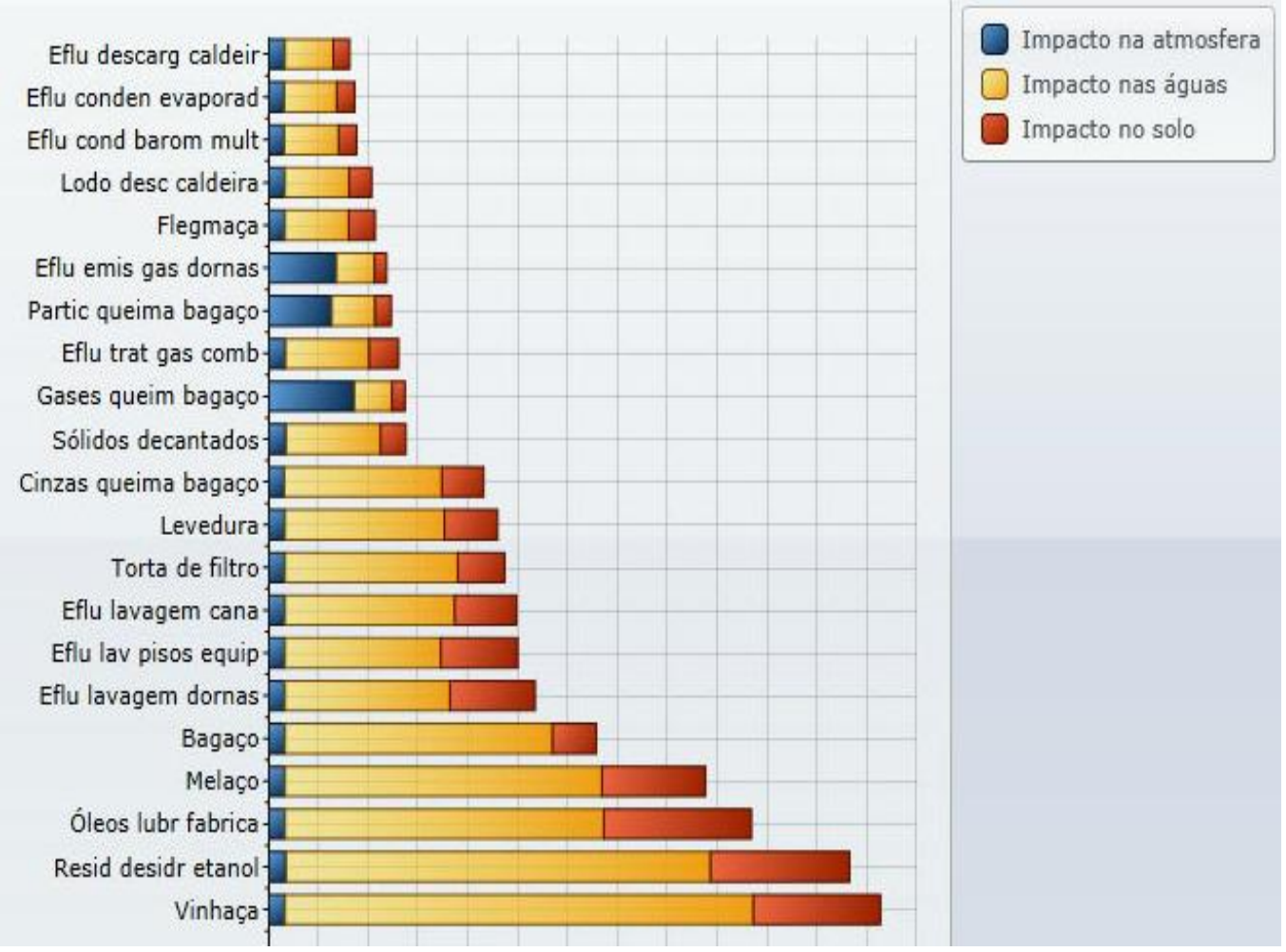

Fonte: elaboração própria

Tabela 3 - Resultados tabelados da aplicação do método AHP nas comparações paritárias entre todos os resíduos e subprodutos (em azul: "alto impacto ambiental”; em amarelo: "médio impacto ambiental"; em verde: "baixo impacto ambiental")

\begin{tabular}{|l|l|l|l|l|}
\hline Resíduo/subproduto & $\begin{array}{l}\text { Impacto } \\
\text { total relativo }\end{array}$ & $\begin{array}{l}\text { Impacto na } \\
\text { atmosfera }\end{array}$ & $\begin{array}{l}\text { Impacto } \\
\text { nas águas }\end{array}$ & $\begin{array}{l}\text { Impacto } \\
\text { no solo }\end{array}$ \\
\hline 1. Vinhaça & 12.27 & 0.32 & 9.40 & 2.55 \\
\hline 2. Resíduos da desidratação etanol & 11.65 & 0.34 & 8.52 & 2.79 \\
\hline 3. Óleos lubrificantes da fabrica & 9.69 & 0.32 & 6.40 & 2.96 \\
\hline 4. Melaço & 8.75 & 0.32 & 6.36 & 2.08 \\
\hline 5. Bagaço & 6.56 & 0.32 & 5.37 & 0.88 \\
\hline 6. Efluente de lavagem das dornas & 5.33 & 0.32 & 3.31 & 1.71 \\
\hline 7. Efluente da lavagem pisos e equipamentos & 4.99 & 0.32 & 3.13 & 1.54 \\
\hline 8. Efluente de lavagem da cana & 4.97 & 0.32 & 3.41 & 1.24 \\
\hline 9. Torta de filtro & 4.73 & 0.32 & 3.47 & 0.94 \\
\hline 10.Levedura & 4.58 & 0.32 & 3.20 & 1.07 \\
\hline 11.Cinzas da queima do bagaço & 4.31 & 0.31 & 3.16 & 0.84 \\
\hline 12.Sólidos decantados (lagoas de decantação) & 2.75 & 0.34 & 1.90 & 0.51 \\
\hline 13. Gases da queima do bagaço & 2.73 & 1.71 & 0.76 & 0.26 \\
\hline $\begin{array}{l}\text { 14.Efluente do tratamento dos gases de combustão da } \\
\text { caldeira }\end{array}$ & 2.60 & 0.33 & 1.68 & 0.59 \\
\hline 15.Particulados gerados na queima do bagaço & 2.45 & 1.26 & 0.87 & 0.32 \\
\hline 16.Efluente das emissões gasosas nas dornas & 2.36 & 1.35 & 0.77 & 0.24 \\
\hline 17.Flegmaça & 2.13 & 0.32 & 1.28 & 0.53 \\
\hline 18.Lodo descarga caldeira & 2.06 & 0.32 & 1.29 & 0.45 \\
\hline $\begin{array}{l}\text { 19.Efluente dos condensadores barométricos ou } \\
\text { multijatos }\end{array}$ & 1.76 & 0.31 & 1.09 & 0.36 \\
\hline 20.Efluente condensado dos evaporadores & 1.72 & 0.31 & 1.05 & 0.36 \\
\hline 21.Efluente de descarga das caldeiras & 1.62 & 0.32 & 0.97 & 0.33 \\
\hline Fonte: elaboraça propra & & & \\
\hline
\end{tabular}

Fonte: elaboração própria 
Observa-se que a vinhaça foi o resíduo ponderado como o de maior impacto relativo $(12,27 \%)$, resultado que se alinha à opinião geral entre os pesquisadores do assunto, que apontam o vinhoto como o principal subproduto da produção sucroenergética. A vinhaça é riquíssima em matéria orgânica (variando de 20000 a $35000 \mathrm{mg} / \mathrm{l}$ ) e apresenta $\mathrm{pH}$ ácido, na faixa de 5 a 5,5, o que representa elevado risco potencial de contaminação, tanto do solo como de qualquer tipo de manancial, seja superficial ou subterrâneo.

Os resíduos da desidratação do etanol hidratado foram classificados em segundo lugar na escala ponderativa de impacto ambiental $(11,65 \%)$. No processo de desidratação do etanol as usinas têm dado preferência à utilização do método de adsorção seletiva chamado de "peneira molecular", que são zeólitas sintéticas compostas de alumínio e silício. Este material apresenta poros microscópicos muito pequenos para as moléculas do álcool etílico, no entanto são suficientemente grandes para permitir a passagem das moléculas de água. Quando o etanol passa, não fica retido na zeólita, pois não sua molécula é demasiada grande para entrar nos pequenos orifícios. Já a molécula de água, que é menor, consegue entrar e fica adsorvida. Com o tempo todos os orifícios da zeólita ficam cheios de água, então é necessário regenerá-la, o que é feito com o uso de vácuo. Elimina-se a água e a peneira está pronta para ser reutilizada. Desta forma, retira-se, por meio deste método, etanol anidro de alta qualidade, sem resíduos químicos. No entanto, a zeólita tem vida média de oito anos e após isso deve ser descartada. Trata-se de um material sempre em contato com o etanol e, portanto, de elevado potencial de contaminação de solo e águas.

Em terceiro lugar no impacto ambiental potencial foram classificados os óleos lubrificantes da fábrica $(9,69 \%)$. A tecnologia de processamento da cana utiliza os mancais hidrodinâmicos em inúmeras das etapas produtivas, pois estes suportam altas cargas e altas rotações com grande vida útil. Os mancais são conjuntos mecânicos, em geral de ferro ou de bronze, destinados a suportar as solicitações de carga, de peso e de rotação dos eixos. Entre o eixo e o mancal injeta-se óleo lubrificante sob pressão, o qual formará película ou filme entre estes, reduzindo consideravelmente o atrito. O óleo lubrificante usado apresenta hidrocarbonetos e metais, tais como o ferro, chumbo, zinco, cobre, cromo, níquel e cádmio. Se lançado no solo, o óleo se infiltra levado pela água da chuva. Além de contaminar o solo vai contaminar os lençóis freáticos subterrâneos. Se lançado nas águas superficiais dá origem a uma camada que impede a oxigenação da água e a fotossíntese das plantas aquáticas, que por sua vez nutrem os peixes.

Em quarto lugar no impacto ambiental potencial foi classificado o melaço $(8,75 \%)$. O melaço não constitui propriamente um resíduo, e sim um subproduto, ou seja, o mel final, mais conhecido como melaço, que veio do processo de produção do açúcar, será utilizado para a produção de etanol. O melaço é constituído principalmente de açúcares como frutose, e glicose e sacarose que não foi cristalizada na produção de açúcar. Apesar de poder ser utilizado como 
fertilizante (em sua composição estão presentes nitrogênio, fosfatos, cálcio e magnésio bem como zinco, manganês, cobre, ferro e micronutrientes) e como alimento para animais, o melaço é muito poluente por ser muito concentrado, com até $85^{\circ}$ Brix, portanto com DBO elevada. Haverá problemas ambientais se o melaço chegar ao solo ou às águas.

Em quinto lugar no impacto ambiental potencial foi classificado o bagaço $(6,56 \%)$. O bagaço da cana apresenta-se como um dos maiores resíduos sólidos resultantes da atividade do setor sucroenergético. O bagaço tem-se prestado à produção de energia por meio da sua queima em caldeiras para a produção de vapor. O vapor será utilizado na produção de energia mecânica, por sua vez transformada em energia elétrica na própria usina. No entanto, o bagaço pode ser utilizado na produção de ração animal, na produção de papel, papelão e aglomerados, na indústria química, como sólido alternativo na construção civil e na produção de biomassa. Trata-se de um resíduo composto basicamente por fibra (celulose) e água, contendo também certa quantidade de açúcar ( 2 a $3 \%$ do peso úmido do bagaço) e pH baixo (ao redor de 5,6). O bagaço, pela degradação da celulose, da hemicelulose e da lignina pode ter efeito enormemente poluidor nas águas se for descartado neste meio, podendo aumentar significativamente os níveis de DBO.

Em sexto lugar no impacto ambiental potencial foi classificado o efluente de lavagem das dornas $(5,33 \%)$. As destilarias brasileiras parecem dar preferência à fermentação do mosto por meio do processo descontínuo ou em bateladas, pois no que se refere à assepsia, o processo em bateladas é considerado o mais seguro. Neste tipo de processo, ao final de cada batelada o reator (dorna) deve ser lavado, diminuindo assim os riscos de contaminação microbiana. Realizam-se várias pequenas fermentações de modo que cada reator é cheio com mosto, e a fermentação é processada em uma dorna de cada vez. Para a empresa, o processo descontínuo proporciona menor grau de incrustações, menor contaminação no processo, menor uso de antibióticos ou biocidas e maior eficiência na fermentação. Considera-se que a água de lavagem das dornas tem efeito poluidor análogo ao do vinhoto, entretanto bem mais diluído, cerca de $20 \%$ do vinhoto.

Em sétimo lugar no impacto ambiental potencial foi classificado o efluente de lavagem de pisos e equipamentos $(4,99 \%)$. As usinas interrompem periodicamente o seu funcionamento com o objetivo de realizar lavagem geral dos equipamentos, enquanto os pisos são lavados com mais frequência, sem a necessidade da interrupção do trabalho. As características das águas de lavagem dos pisos e equipamentos não são uniformes. A DBO varia na faixa de centenas até milhares de $\mathrm{mg} / \mathrm{L}$ e o pH desde muito ácido até muito alcalino. Pode também estar contaminado com graxas e óleos. Trata-se de um efluente com alto potencial de contaminação das águas e do solo.

Em oitavo lugar no impacto ambiental potencial foi classificado o efluente de lavagem da cana $(4,97 \%)$. A lavagem da cana é uma operação preliminar realizada pela usina quando a cana não está picada, ou seja, quando é colhida inteira. Seu objetivo é eliminar as impurezas minerais 
que se agregaram à cana ao longo das etapas de cultivo, corte e carregamento até a indústria. É uma operação de acarreta perdas de açúcares na cana, os quais se dissolvem na água no momento da lavagem. O efluente gerado é poluente e se caracteriza por altas taxas de DBO, muita matéria orgânica, alta concentração de sólidos e pH baixo.

O nono resíduo classificado em termos do seu impacto ambiental foi a torta de filtro $(4,73 \%)$. O processo industrial para a produção do açúcar e do etanol passa por uma etapa denominada "clarificação", a qual consiste na purificação do caldo obtido no processo anterior de extração do caldo (popularmente chamado de "moagem"). Nesse processo de purificação adicionase ao caldo de cana (já aquecido) uma suspensão de hidróxido de cálcio, que promove a elevação do pH. Como consequência, ocorre a floculação de colóides orgânicos, bem como a precipitação de sais de cálcio, sobretudo fosfato. A suspensão obtida passa então por processo de decantação ou sedimentação, resultando em caldo límpido por cima e uma borra ou lodo por baixo. Este lodo é formado pelos compostos orgânicos e inorgânicos que foram insolubilizados e ainda contém certa quantidade de caldo clarificado que deve ser recuperado por um processo de filtração ou prensagem. No entanto, como a borra não tem consistência apropriada para passar por filtração é misturada a bagaço de cana finamente moído (chamado na indústria de "bagacinho"). Em seguida, esta mistura é submetida à filtração a vácuo resultando num material com umidade em torno de $75 \%$ que se denomina torta de filtro. As características da torta de filtro são afetadas por diversos fatores: estágio de maturação da cana, variedade da cana, tipo de solo utilizado no cultivo, variações no processo de clarificação do caldo, entre outros. O nitrogênio orgânico, cálcio e fósforo estão entre os elementos principais. É um resíduo constituído basicamente por bagaço de cana (11\% de lignina, $34 \%$ de hemicelulose e $38 \%$ de celulose) com uma pequena fração mineral na qual o principal elemento é o silício. Apesar de seu intensivo uso como adubo na lavoura da cana, a torta de filtro tem alto potencial poluente principalmente com relação às águas, podendo acarretar significativos danos aos mananciais superficiais ou subterrâneos, se indevidamente disposta no ambiente.

O décimo resíduo classificado em termos do seu impacto ambiental foi a levedura $(4,58 \%)$. A levedura é um subproduto da indústria alcooleira que provém da fermentação anaeróbica do caldo de cana ou do mel final no processo de produção do etanol. Retira-se a levedura a partir da centrifugação do vinho ou partir do fundo das dornas de fermentação. Posteriormente, é submetida a um processo de secagem. Como é um material rico em proteínas e altamente concentrado em vitaminas do complexo $\mathrm{B}$, é largamente utilizado na composição de ração para animais e também muito utilizada na indústria alimentícia. Como mais de $87 \%$ do peso sobre a matéria seca é composto de matéria orgânica, trata-se de um subproduto potencialmente poluidor, principalmente de águas superficiais e subterrâneas. 
O décimo primeiro resíduo classificado em termos do seu impacto ambiental foram as cinzas provenientes da queima do bagaço $(4,31 \%)$. As cinzas são na indústria sucroenergética, um resíduo sólido produzido a partir da queima do bagaço nas caldeiras para a produção do vapor. São resíduos atualmente encaminhados, juntamente com torta de filtro, à lavoura da cana. O dióxido de silício $\left(\mathrm{SiO}_{2}\right)$ é o composto predominante nas cinzas (cerca de $60 \%$ da massa), representando os óxidos de potássio $\left(\mathrm{K}_{2} \mathrm{O}\right)$, óxidos de magnésio $(\mathrm{MgO})$, óxidos de fósforo $\left(\mathrm{P}_{2} \mathrm{O}_{5}\right)$ e óxidos de cálcio $(\mathrm{CaO})$ conjuntamente, cerca de $32 \%$ da massa da cinza do bagaço. Apesar de quimicamente estável, não tóxica, e não conter material orgânico dissolvido, as cinzas são potencialmente poluidoras de águas superficiais.

O décimo segundo resíduo classificado em termos do seu impacto ambiental foram os sólidos ou lodo decantado das lagoas de sedimentação (2,75\%). Nas lagoas de decantação as águas residuárias da fabricação sucroalcooleira são depositadas de forma que os sólidos que se encontram em suspensão, os quais possuem maior massa específica que o líquido em tratamento, possam decantar gradualmente. Os materiais flutuantes, como graxas e óleos, os quais possuem uma menor massa específica que o líquido em tratamento sobem para a superfície e dessa forma podem ser separados, removidos e conduzidos à armazenagem específica para futuro tratamento. O principal risco contaminante reside nas águas superficiais, pois se trata de lama misturada a sólidos, porém com taxa de DBO muito variada.

O décimo terceiro resíduo classificado em termos do seu impacto ambiental foram os gases da queima do bagaço (2,73). Os gases da queima do bagaço são liberados ao ambiente contribuindo para o efeito estufa. Na queima do bagaço os seguintes gases poluentes são liberados: metano $\left(\mathrm{CH}_{4}\right)$, monóxido de carbono $(\mathrm{CO})$, óxido nitroso $\left(\mathrm{N}_{2} \mathrm{O}\right)$, óxidos de nitrogênio $\left(\mathrm{NO}_{\mathrm{x}}\right)$ e dióxido de carbono $\left(\mathrm{CO}_{2}\right)$. Aqui há uma situação não conclusiva entre os cientistas. Apesar de encontrarmos na literatura afirmações de que as emissões de $\mathrm{CO}_{2}$ pela queima não devam ser contabilizadas em virtude do ciclo renovável da biomassa, há autores que contestam esta hipótese e afirmam que esta soma não é zero, ou seja, há maior volume produzido de $\mathrm{CO}_{2}$ do que capturado pela cana de açúcar. Por outro lado, há especialistas que consideram que a fixação de $\mathrm{CO}_{2}$ pelo canavial se dá em volume ainda maior que a emissão pela combustão do bagaço, pois parte deste $\mathrm{CO}_{2}$ se transforma em açúcar, não em etanol, e desse modo nem todo $\mathrm{CO}_{2}$ retorna para o ambiente. De qualquer forma, não se contesta que o metano e o óxido nitroso tenham forte impacto no efeito estufa, sendo o metano vinte vezes mais poluente que o dióxido de carbono. Deste modo, os gases emitidos pela queima do bagaço têm efeito poluidor na atmosfera.

O décimo quarto resíduo classificado em termos do seu impacto ambiental foi o efluente do tratamento dos gases de combustão da caldeira (2,60\%). Trata-se de um efluente gerado nos retentores tipo via úmida ou via seca (multiciclones) para retenção do material particulado (MP) 
emitido no processo de combustão do bagaço. Apesar de conter certo teor de matéria orgânica, apresenta uma baixa taxa de DBO (de 100 a $300 \mathrm{mg} / \mathrm{L}$ de DBO). Entretanto, é um efluente muito quente, com temperatura chegando até $80^{\circ} \mathrm{C}$ e uma alta carga de fuligem, que são os sólidos dispersos na água. Isto não permite seu despejo diretamente em corpos d'água nem na lavoura.

O décimo quinto resíduo classificado em termos do seu impacto ambiental foram os particulados gerados na queima do bagaço $(2,4 \%)$. Os gases originados no processo de queima do bagaço na caldeira são retirados por exaustão forçada por meio de ventiladores. Juntamente com os gases em movimento ascendente são arrastadas partículas de fuligem, pequenos fragmentos de bagacilho não totalmente queimado e sílica. Estes fragmentos particulados possuem relativo grau poluente, principalmente na atmosfera. Enquanto os materiais mais pesados e grosseiros podem depositar-se em áreas mais próximas à indústria, os materiais particulados menores e mais leves podem dispersar-se remotamente.

O décimo sexto resíduo classificado em termos do seu impacto ambiental foram os efluentes das emissões gasosas nas dornas de fermentação (2,36\%). Este efluente é constituído basicamente pelo gás $\mathrm{CO}_{2}$ produzido pela fermentação do mosto proveniente do caldo da cana. Os reatores de fermentação com milhões de litros liberam quantidades expressivas de $\mathrm{CO}_{2}$ no ambiente. Há a estimativa de que para cada $92 \mathrm{~g}$ de etanol fabricado, são lançados $88 \mathrm{~g}$ de gás carbônico na atmosfera. Apesar de existir atualmente tecnologia para captura e armazenamento deste $\mathrm{CO}_{2}$ são raras as empresas que o fazem, dadas as dificuldades comerciais e logísticas encontradas pelas usinas neste tipo de mercado.

O décimo sétimo resíduo classificado em termos do seu impacto ambiental foi a flegmaça $(2,13 \%)$. O vinho proveniente do processo de fermentação do mosto é depurado duas vezes em uma coluna de destilação. A primeira destilação tem como objetivo eliminar parte dos ésteres e aldeídos, e a segunda destilação fracionada o vinho em vinhaça e flegma, que é o produto principal da destilação. O flegma passa pelo processo de retificação com o objetivo de produzir álcool hidratado, gerando por um lado o etanol bruto ou de segunda e por outro lado os resíduos flegmaça e óleo fúsel. A flegmaça é uma água com traços de óleo de fúsel com baixo potencial poluente. Aponta-se uma produção média 2,8 litros de flegmaça para cada litro de etanol produzido.

O décimo oitavo resíduo classificado em termos de impacto ambiental foi lodo de descarga da caldeira (2,06\%). Trata-se de um resíduo sólido vertido na atividade de descarga da caldeira, a qual tem como objetivo eliminar este material que se acumula no fundo da caldeira e prejudica sua operação, pois se depositam no fundo da caldeira obstruindo a transferência de calor e provocando seu superaquecimento. Este lodo é composto basicamente por sílica, cálcio e magnésio. É um resíduo potencialmente pouco poluente para o solo ou para os mananciais. Algumas usinas, dado a 
tecnologia da caldeira em uso, com alto nível de tratamento e controle das características da água de suas caldeiras e da em uso, não chegam a produzir tal resíduo.

O décimo nono resíduo classificado em termos do seu impacto ambiental foram os efluentes dos condensadores barométricos ou multijatos (1,76\%). Os condensadores barométricos são empregados com o objetivo de condensar o vapor resultante do último efeito da etapa de evaporação do caldo ou condensar o vapor que é resultante do processo de cozimento na produção de açúcar, estabelecendo o vácuo suficiente para um regime operacional estável. O efluente descarregado pelos condensadores barométricos exibe baixo potencial poluente, pois há baixa carga orgânica, baixa DBO (até 40mg/L DBO), com temperaturas moderadas (em torno de $45^{\circ} \mathrm{C}$ ).

$\mathrm{O}$ vigésimo resíduo classificado em termos do seu impacto ambiental foram os efluentes condensados nos evaporadores $(1,72 \%)$. Na fabricação do açúcar, o caldo clarificado, o qual é muito rico em sacarose, deve ter a maior parte de sua água removida. Na primeira etapa deste processo, chamado de "concentração do caldo", utiliza-se equipamentos denominados evaporadores de múltiplo efeito. Nesses evaporadores, por exemplo, no evaporador de primeiro efeito, a água condensada formada é de origem do vapor de escape (a qual é muito límpida e DBO quase inexistente). Em algumas usinas esta água pode retornar para a caldeira e ser reutilizada para produzir mais vapor. A partir do segundo efeito a água condensada formada vem da condensação do vapor vegetal, o que incrementa um pouco a DBO, pois os compostos voláteis do caldo vão fazer parte da água condensada. A tendência é que à medida que se encaminha para o último corpo exista um aumento da DBO, pois com o vácuo ocorre arraste de micro gotas de caldo clarificado. Na maior parte destes equipamentos existe um mecanismo denominado "separador de arraste" para evitar este arraste, porém se este estiver sobrecarregado, pode deixar passar as gotas de caldo, aumentando a DBO. Contudo, de uma maneira geral, retiram-se desses equipamentos efluentes com baixa DBO, ainda menor que os efluentes classificados em décimo nono lugar. Desta forma, cabe aqui uma explanação adicional a respeito do décimo nono e vigésimo resíduos. No último corpo de evaporação (último efeito), no qual o vácuo é mais intenso, o arraste de micro gotas é muito maior do que nos efeitos anteriores. Isso explica porque a DBO dos efluentes dos condensadores barométricos ou multijatos deve apresentar-se maior do que nos efluentes condensados nos evaporadores.

O vigésimo primeiro resíduo classificado em termos do seu impacto ambiental foi o efluente de descarga das caldeiras $(1,62 \%)$. As caldeiras de queima do bagaço realizam purgas periódicas, as quais têm como objetivo eliminar o lodo e a ferrugem acumulados no fundo. Deste modo, realiza-se frequentemente a descarga desses materiais. Trata-se de um material de DBO muito baixa, porém concentrado em lodo e em sólidos solúveis, não devendo ser despejado em mananciais. 


\section{Considerações finais}

O processamento industrial sucroalcooleiro envolve transformações químicas, físicas e bioquímicas para transformar a cana de açúcar em açúcar e etanol. Trata-se de um processo de produção do tipo contínuo puro, em que a matéria prima não pode ser discretizada, dado que toda a produção sucroalcooleira é realizada a partir do caldo extraído da cana, o qual é um líquido e, portanto não fragmentável unitariamente.

A ponderação do impacto ambiental de todos os resíduos e subprodutos da produção sucroenergética pode ser considerada um problema de resolução complexa, pois têm causas e efeitos só percebidos pela reflexão e requerem visão dedutiva auxiliada pela experiência, ou seja, pela vivência anterior com as variáveis em questão. Trata-se de um problema que envolve: resíduos/subprodutos com grandes diferenças na natureza química e física; diversos efeitos nocivos que estes podem ter se mal destinados em diferentes ambientes naturais (águas, solo e atmosfera); e alterações que esses efeitos que podem ter com o passar do tempo.

Desta forma, para lidar com tal complexidade aplicamos o método AHP, o qual é interessante quando os elementos constituintes do processo de tomada de decisão são difíceis de quantificar ou comparar, ou quando o relacionamento entre os elementos é dificultado por terminologias ou perspectivas muito distintas.

A utilização do método AHP envolve a sinopse matemática de várias arbitragens sobre o problema de decisão. A questão central do método está calcada na determinação do peso com que os fatores individuais do nível mais baixo da hierarquia influenciam o fator máximo, o objetivo geral. Mais especificamente, o método caminha na direção da obtenção de pesos numéricos para alternativas com relação a subobjetivos e, para subobjetivos com relação a objetivos de ordem mais elevada.

Dentro disso, nossa estrutura hierárquica teve como objetivo geral a ponderação do impacto dos resíduos e subprodutos da produção sucroalcooleira. Logo abaixo deste, três subobjetivos foram definidos: impacto nas águas, impacto no solo e impacto na atmosfera. Por meio da aplicação do método AHP, concluímos que a produção sucroenergética tem alto potencial de contaminação dos mananciais superficiais e subterrâneos, médio potencial de contaminação do solo e pequeno potencial de contaminação da atmosfera.

A partir da primeira etapa de produção industrial, a recepção da cana, até a última etapa, o armazenamento do açúcar e do etanol, este trabalho identificou vinte e um resíduos e subprodutos gerados nas etapas de fabricação do açúcar e do etanol. Estes resíduos/subprodutos foram tomados como as alternativas a serem ponderadas com relação aos subobjetivos: impacto nas águas, impacto no solo e impacto na atmosfera. 
Tanto os resíduos como os subprodutos identificados podem ser ou não poluentes. Isto depende da capacidade do sistema natural em suportar as quantidades de material nele introduzido. Desta forma, nas análises por meio do método AHP, os avaliadores consideraram o resíduo ou subproduto sendo eliminado ou despejado diretamente no meio natural, pois na adoção do método foi necessário adotar-se um critério de destinação do despejo. Esta, entretanto, não é uma situação irreal, pois são muitos os relatos encontrados na literatura sobre acidentes ambientais ocorridos em diversas etapas do processo produtivo das usinas sucroenergéticas com graves prejuízos ao meio natural.

Como resultado, observamos que todos os resíduos/subprodutos gerados, exceto o efluente das emissões gasosas das dornas de fermentação, os particulados gerados durante a queima do bagaço e os gases da queima do bagaço, possuem maior impacto ambiental potencial nas águas.

Observamos também que os quatro primeiros resíduos/subprodutos mais impactantes, que são a vinhaça, os resíduos da desidratação do etanol, os óleos lubrificantes da fábrica e o melaço possuem impacto total relativo situados numa faixa que vai de $8 \%$ a $13 \%$. Deste modo, arbitramos que estes poluentes são pertencentes ao grupo de alto impacto ambiental.

Situados no grupo de médio impacto ambiental estão o bagaço, os efluentes de lavagem das dornas, o efluente da lavagem de pisos e equipamentos, o efluente de lavagem da cana, a torta de filtro, a levedura e as cinzas da queima do bagaço com impacto total relativo que vai de $2 \%$ a $7 \%$.

Situados no grupo de baixo impacto ambiental estão os sólidos decantados nas lagoas de sedimentação, os gases da queima do bagaço, o efluente do tratamento dos gases de combustão da caldeira, os particulados gerados na queima do bagaço, o efluente das emissões gasosas das dornas de fermentação, a flegmaça, o lodo de descarga das caldeiras, o efluente dos condensadores barométricos ou multijatos, o efluente dos evaporadores e o efluente de descarga das caldeiras com impacto total relativo que vai de $1 \%$ a $3 \%$.

\section{Agradecimentos}

Os autores agradecem à Fundação de Amparo à Pesquisa do Estado de São Paulo (FAPESP, processo 2011/08648-4) pelo apoio financeiro à pesquisa.

\footnotetext{
Abstract

The objective of this work is to develop and present an inventory of waste and by-products of sugar energy production and, from this, perform the quantitative estimation of the relative environmental impact of each of them. For that were mapped and analyzed the productive stages of sugar energy production and identified wastes and byproducts generated in each of them. Then, we applied the Analytic Hierarchy Process method (AHP) to establish the relative weights of each waste or byproduct in terms of its potential impact on the environment. As a result, we identified twenty-one waste and by-products of sugar energy production potentially polluting. These wastes/by-products
} 
were characterized according to their physic/chemical composition and manner in which they are generated within the manufacturing processes. We also conclude that the production of sugar and ethanol has a higher environmental impact on the waters (67\%), followed by soil (23\%) and atmosphere (10\%).

Key-words: environmental impacts of sugar energy production; waste and by-products of sugar energy production, weighting of environmental impact of wastes of sugar energy production.

\section{Referências}

ANA. Manual de conservação e reuso da água na agroindústria sucroenergética. Agência Nacional da Águas FIESP - ÚNICA- CTC - Brasília, 2009. Disponível em: 〈www.fiesp.com.br/ambiente/downloads/publicaguab.pdf〉 Acesso em 13 abril de 2012.

CASTRO, S. O.; MOREL, E. P.; LEÃO, G. T.; SELLITTO, M. A. Metodologia para avaliação de desempenho ambiental em fabricação utilizando um método de apoio á decisão multicriterial. Estudos tecnológicos, v.1, n.2, p.21$29,2005$.

COSTA, J. F. S.; CORREIA, M. G.; SOUZA, L. T. T. Utilização do Método de Análise Hierárquica na Escolha de Software Estatístico para a Demanda de Uma Universidade Pública. Produto \& Produção, v.12, n.1, p.42 - 59, 2011.

FIPA. Boletim informativo da Federação das Indústrias Portuguesas Agro-Alimentares. 2007. Disponível em <http://www.fipa.pt/pdf/fipaflash95.pdf acessado em Janeiro/2013> Acesso em 5 de janeiro de 2013.

MACHADO, A. G. C.; SILVA, J. C. Estratégia empresarial e práticas ambientais: evidências no setor sucroalcooleiro. Revista Brasileira de Gestão de Negócios, v. 12, n. 37, p. 405-424, 2010.

MARAFANTE, L. J. Tecnologia da fabricação do açúcar e do álcool. São Paulo: Ícone, 1993.

OLIVEIRA, A. A.; COSTA, J. A. F.; NETO, M. V. S. Aplicação do método de análise hierárquica na tomada de decisão para a adoção de computação em nuvem. In: SIMPOI, 2011. São Paulo: FGV-EAESP, 2011.

OLIVEIRA, S. M.; HANSEN, A. O.; SILVA, T. N.; PEDROZO, E. A.; BOLDIN, V. P. Responsabilidade sócioambiental no setor sucroalcooleiro: um estudo de caso na Pioneiros Bioenergia S/A. Revista Eletrônica de Gestão, v. 2, n. 1, p. 111-134, 2009.

PIACENTE, F. J. Agroindústria canavieira e o sistema de gestão ambiental: o caso das usinas localizadas nas Bacias Hidrográficas dos rios Piracicaba, Capivari e Jundiaí. Dissertação (Mestrado) - IC-UNICAMP. Campinas: UNICAMP, 2005.

REBELATO, M. G.; MADALENO, L. L; RODRIGUES, A. M. Um estudo sobre a aplicabilidade do sistema puxado de produção na fabricação de açúcar. Revista Gestão Industrial, v.7, n.1, pp. 228-246, 2011.

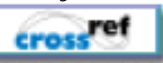

REBELATO, M. G.; MADALENO, L. L; RODRIGUES, A. M. Um estudo sobre a aplicabilidade do Just-In-Time na fabricação do etanol. Revista Produção Online, v.12, n. 3, pp. 703-728, 2012.

ROHRICH, S. S.; CUNHA, J. C. A Proposição de uma taxonomia para análise da gestão ambiental no Brasil. Revista de Administração Contemporânea, v. 8, n. 4, p. 81-97, 2004.

cross ref

SAATY, T. L. Método de Análise Hierárquica. São Paulo: Makron Books, 1991.

SHIMIZU, T. Decisão nas organizações. $3^{\text {a }}$ Ed. São Paulo: Atlas, 2010. 


\section{Dados dos autores:}

Nome completo: Marcelo Giroto Rebelato

Filiação institucional: FCAV - UNESP - Jaboticabal

Departamento: Economia Rural

Função ou cargo ocupado: Professor

Endereço completo para correspondência (bairro, cidade, estado, país e CEP): Via de Acesso Prof.

Donato Castellane s/n - 14884-900 - Jaboticabal - SP

Telefones para contato: 16 3209-2635

e-mail:mgiroto@fcav.unesp.br

Nome completo: Leonardo Lucas Madaleno

Filiação institucional: Centro Paula Souza - FATEC/Jaboticabal

Departamento: não há

Função ou cargo ocupado: Professor

Endereço completo para correspondência (bairro, cidade, estado, país e CEP): Via de Acesso Prof.

Donato Castellane s/n - 14884-900 - Jaboticabal - SP Telefones para contato: 1632026519

e-mail: leoagro@gmail.com

Nome completo: Andréia Marize Rodrigues

Filiação institucional: FCAV - UNESP - Jaboticabal

Departamento: Economia Rural

Função ou cargo ocupado: Professora

Endereço completo para correspondência (bairro, cidade, estado, país e CEP): Via de Acesso Prof.

Donato Castellane s/n - 14884-900 - Jaboticabal - SP

Telefones para contato: 16 3209-2635

e-mail: andreiamarize@fcav.unesp.br

Enviado em: 24/04/2013

Aprovado em: 07/07/2013 